\title{
1
}

\section{Shipping and Globalization in the Post-War Era: Contexts, Companies, Connections}

\author{
Niels P. Petersson, Stig Tenold and Nicholas J. White
}

\section{Introduction}

In the early autumn of 2016, the major South Korean shipping company Hanjin filed for bankruptcy. The collapse of the company, which had specialized in container shipping, left much of its fleet marooned at sea. More than 60 ships, with cargoes and sailors, were involved. If the ships went to port, it was likely that the creditors would attempt to seize the

N. P. Petersson $(\varangle)$

Sheffield Hallam University, Sheffield, UK

e-mail: n.p.petersson@shu.ac.uk

S. Tenold

Department of Economics, NHH - Norwegian

School of Economics, Bergen, Norway

e-mail: stig.tenold@nhh.no

N. J. White

School of Humanities and Social Science, Liverpool John Moores

University, Liverpool, Merseyside, UK

e-mail: n.j.white@ljmu.ac.uk

(C) The Author(s) 2019

N. P. Petersson et al. (eds.), Shipping and Globalization in the Post-War Era,

Palgrave Studies in Maritime Economics,

https://doi.org/10.1007/978-3-030-26002-6_1 
vessels. Some ports were unwilling to admit Hanjin ships out of fear that the company would not be able to pay the costs of docking and unloading, or that the vessels, with disputed ownership, would occupy valuable berths for long periods of time. ${ }^{1}$

The case received substantial publicity. One reason for this was the fact that Hanjin was a leading shipping company, controlling the seventh largest container fleet in the world. Another reason-and the one that brought the case into non-business media outlets - was the timing of the incident. The Hanjin ships were carrying goods intended to fill shop shelves before the Christmas period. A number of large retailers in Europe and North America feared that thousands of containers with valuable cargo on their way from Asia would not reach their destinations on time. Was Hanjin really the Grinch that would steal Christmas, as a Bloomberg journalist suggested? ${ }^{2}$

The incident found a temporary solution, and Christmas was saved. However, there are several aspects of the Hanjin debacle that illuminate the topics that we deal with in this book-shipping and globalization in the period after World War II. First, the example illustrates the crucial role that foreign trade plays in the economies of most nations. Shipping is crucial in ensuring the smooth operation of this trade system. Second, the case shows how East Asian economies have managed to obtain a central position in the global production system, supplying finished goods to consumer markets in Europe and North America. Third, the fact that the company involved was South Korean illustrates that not only manufacturing production, but also a service industry such as shipping has increasingly moved towards Asia. Finally, the sheer amount of cargo involved is a testament to the manner in which the shipping industry has grown in the post-war period, where ships and companies have become ever larger.

Shipping was both an example and an engine of globalization in the post-war era. In turns, the shipping industry experienced and pioneered, mirrored and enabled key developments that led to the present-day globalized economy. Shipping was among the first industries exposed to fierce globalized competition. The shipping industry pioneered many of the

\footnotetext{
${ }^{1}$ See Ilmer (2016) and The Economist (2016) for news reports about the case.

${ }^{2}$ Cooper (2016).
} 
organizational models and mechanisms that characterize the current corporate landscape. The slicing up of the value chain and the strategic location of business functions is one example, the use of low-cost and low-tax jurisdictions, often in small countries 'offshore', is another. Meanwhile, many business strategies and dynamics in shipping reflected those in the wider economy: strategic management, outsourcing, the focus on core businesses. As the main means of production - the ship — is mobile, questions of nationality and legal domicile are far more complex in shipping than in other industries. This increasingly transnational nature of the industry in turn stimulated the emergence of new forms of global governance.

Cheap mass transport, first for bulk commodities and oil and then for general cargo, underpinned the growth of world trade, the migration of production to Asia's Newly Industrialized Countries, and the emergence of complex global supply chains. The container is often seen as the 'typical' symbol of globalization, and the rise of container shipping coincided with the strong growth of international trade after World War II. Container shipping 'changed the world' and 'made the world smaller and the world economy bigger', if we are to believe the titles of the books published to commemorate the '50th anniversary' of container shipping in 2006. ${ }^{3}$ Yet container shipping, which primarily involves the transport of finished goods, is far from the largest segment of the shipping market. The most important cargoes are raw materials such as oil, ores, grain, etc. The efficient and ever cheaper seaborne transport of such raw materials has been a necessary condition for the increasing division of labour in the world economy. However, such cargoes are primarily transported to and from terminals near mines and factories, and most people never encounter these gigantic ships. On the transport side, shipping has thus contributed to world trade both in a visible and an invisible way.

Without shipping and its ability to forge connections and networks of a global reach, the modern world would look very different. Famously, ships

\footnotetext{
${ }^{3}$ Cudahy (2006) and Levinson (2006); see also Donovan and Bonney (2006). The converted oil tanker Ideal $X$ is usually referred to as the 'first' container ship.
} 
nowadays transport 'ninety per cent of everything' we produce and consume. ${ }^{4}$ However, shipping's effect on today's society reaches far beyond the provision of low-cost transport links, into what economists call the supply side, creating global markets for labour and finance. Today, Filipino sailors are creating value on German-owned ships built and financed in China and flying the flag of the Marshall Islands on a voyage between Australia and the United States. The wider connections forged by offshore companies developed gradually from roots sometimes stretching back into the interwar years and even earlier, with an acceleration from the 1970s. At the same time, shipping still remains embedded in national frames of reference in important respects, including business and worker cultures, regulations enforced under port state controls and national industrial policies.

How can we understand the interaction between globalization and shipping? This book highlights the importance of dialogue connecting historians of various specialist backgrounds as well as social scientists. It demonstrates the value of interdisciplinary approaches to analysing complex connections across various parts of Europe, Asia, Africa, the Americas and Australasia. It throws new light on the transformations of the period since World War II-political, ideological and technological as well as economic - and stimulates further enquiry. It combines the key benefits of a historical perspective, such as awareness of longer-term structural change, context and the dynamic interplay of continuity and change, with social scientists' interest in the forces shaping the present-day world.

The book is divided into three sections entitled Contexts, Companies and Connections. The first section illustrates the usefulness of a multidisciplinary approach, investigating three large-scale historical processes, decolonization, the rise of Asia and the emergence of new structures of international governance, through the lens of shipping. The second section analyses one of the important driving forces of these macro-processesthe companies that created new markets and forged new connections. Our case studies of three liner shipping companies, Maersk, EAC and Ocean, and their very different trajectories provide insight into the strategies and performance of both successful and unsuccessful firms. The third section focuses on shipping's role in the emergence of new global connections at a

${ }^{4}$ George (2013). 
more specific level, studying individual ships' global 'biographies' and how business leaders were breaking down established institutional forms and transcending boundaries between countries and industries. Through the analysis of such examples, the book highlights how shipping was embedded in and contributed to the transformations of business and society in the post-war era.

\section{References}

Cooper, C. (2016, September 9). The Ghost Ships of Hanjin and Why They're Spoiling Christmas. Bloomberg. https://www.bloomberg.com/news/articles/ 2016-09-09/quicktake-q-a-the-shipping-line-that-could-spoil-christmas. Accessed 17 January 2019.

Cudahy, B. J. (2006). Box Boats: How Container Ships Changed the World. New York: Fordham University Press.

Donovan, A., \& Bonney, J. (2006). The Box That Changed the World: Fifty Years of Container Shipping - An Illustrated History. East Windsor: Commonwealth Business Media.

George, R. (2013). Ninety Percent of Everything: Inside Shipping, the Invisible Industry That Puts Clothes on Your Back, Gas in Your Car and Food on Your Plate. New York: Metropolitan Books; published in the UK as Deep Sea and Foreign Going: Inside Shipping, the Invisible Industry That Brings You 90\% of Everything.

Illmer, A. (2016). Hanjin Ships, Cargoes and Sailors Stranded at Sea. BBC News Online. https://www.bbc.com/news/business-37241727. Accessed 17 January 2019.

Levinson, M. (2006). The Box: How the Shipping Container Made the World Smaller and the World Economy Bigger. Princeton: Princeton University Press. The Economist. (2016). Why Billions of Dollars of Goods Are Stuck at Sea. https://www.economist.com/the-economist-explains/2016/09/21/whybillions-of-dollars-of-goods-are-stuck-at-sea. Accessed 17 January 2019. 
Open Access This chapter is licensed under the terms of the Creative Commons Attribution-NonCommercial-NoDerivatives 4.0 International License (http:// creativecommons.org/licenses/by-nc-nd/4.0/), which permits any noncommercial use, sharing, distribution and reproduction in any medium or format, as long as you give appropriate credit to the original author(s) and the source, provide a link to the Creative Commons license and indicate if you modified the licensed material. You do not have permission under this license to share adapted material derived from this chapter or parts of it.

The images or other third party material in this chapter are included in the chapter's Creative Commons license, unless indicated otherwise in a credit line to the material. If material is not included in the chapter's Creative Commons license and your intended use is not permitted by statutory regulation or exceeds the permitted use, you will need to obtain permission directly from the copyright holder.

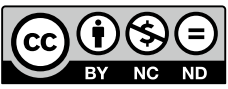

